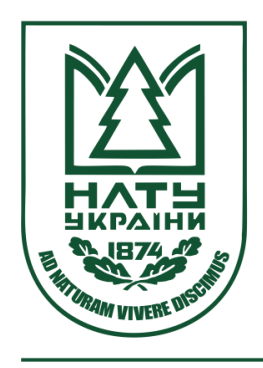

Науковий вісник НЛТУ України Scientific Bulletin of UNFU

https://nv.nltu.edu.ua

https://doi.org/10.36930/40300502

$@ \bigotimes$ Correspondence author

Article received 03.11.2020 p.

Article accepted 17.09.2020 p.

N. Ye. Horbenko

UDC 582.[688.4+678.2]:581.198

nata.horbenko@gmail.com

В. Ф. Левон ${ }^{1}$, Н. В. Скрипченко ${ }^{1}$, Н. Є. Горбенко 2

${ }^{1}$ Національний ботанічний сад імені М. М. Гришка НАН Украӥни, м. Київ, Украӥна

${ }^{2}$ Національний лісотехнічний університет Украйни, м. Львів, Украӥна

\title{
СЕЗОННА ДИНАМІКА ВМІСТУ АНТОЦІАНІВ У ДЕРЕВНИХ ПЛОДОВИХ ЛІАНАХ
}

Наведено дані про вміст антоціанів у пагонах, листках та плодах витких дводомних ліан, зокрема видів і сортів роду $A c-$ tinidia Lindl. та виду Schisandra chinensis (Turcz.) Вaill. Висловлено припущення, що антоціани є біохімічним маркером пристосування досліджуваних видів і сортів витких дводомних ліан до стрес-факторів абіотичної природи. Встановлено, що кількість антоціанів у вегетативних органах рослин змінюється в онтогенезі та залежить від різних чинників навколишнього середовища. Відзначено два піки з максимальним вмістом антоціанів в пагонах ліан, що припадають на період спокою рослин 3 мінімальною температурою та на посушливий період з високою температурою повітря. У період спокою всі досліджувані рослини реагували на значне зниження температури підвищенням вмісту антоціанів у корі пагонів. Порівняння вмісту антоціанів у пагонах різних видів та різної статі в період спокою показали, що менш зимостійкі види актинідії вирізнялись вищим вмістом антоціанів. Це, зокрема, всі чоловічі рослини Actinidia kolomikta (Rupr. \& Maxim.) Maxim., A. arguta (Siebold \& Zucc.) Planch. ex Miq. та A. arguta var. purpurea (Rehder) C. F. Liang ex Q. Q. Chang. Вони, за нашими дослідженнями, менш стійкі порівняно з функціонально жіночими. У період літньої посухи виявлено збільшення кількості антоціанових пігментів у листках усіх дослідних об'єктів, що дає змогу розглядати їх посилений синтез як неспецифічну реакцію рослин у відповідь на несприятливі умови середовища. У період завершення вегетації у листкових пластинках кількість антоціанів була вища порівняно з черешками (на 25-78 \%). Найбільшу різницю за вмістом антоціанів у листках та черешках відзначено для рослин A. kolomikta, які вирізняються найкоротшим періодом вегетації, на відміну від інших видів актинідії. На початку достигання плодів вміст антоціанів у листках актинідії був значно вищий, ніж у плодах. До того ж листки червоноплодих сортів вирізнялись вищим вмістом антоціанів порівняно зі зеленоплодими. Тому можна припустити, що вміст антоціанів у листках актинідії на ранніх етапах розвитку рослин може слугувати індикатором кольору їх плодів, що дуже важливо для селекційної роботи, одним з напрямків якої є відбір червоноплодих форм.

Ключові слова: Actinidia Lindl.; Schisandra chinensis (Turcz.) Вaill.; інтродукція; рослинні пігменти; морозостійкість.

\section{Вступ}

Важливим показником перспективності культивування видів та форм рослин за умов інтродукції $є$ їх адаптивний потенціал, тобто здатність до виживання та відтворення в нових умовах довкілля. Зробити висновок щодо інтенсивності фізіолого-біохімічних змін, які відбуваються у тканинах рослин у період дії стресових факторів, можна за зміною вмісту окремих метаболітів. Серед метаболітів, які найбільш тісно пов'язані зі загальною стійкістю рослин до стресу, є флавоноїди, антоціани, халкони, фенолкарбонові та аскорбінова кислоти, малоновий диальдегід та ін. [8, 13].

Антоціани - це природні речовини 3 групи флавоноїдів, які забарвлюють плоди, листки та пелюстки рослин у кольори від рожевого до чорно-фіолетового. Водночас, вони виконують захисну й антиоксидантну функції у рослинних клітинах, захищаючи їх від різноманітних екстремальних впливів, зокрема від фотопош- кодження, дії субоптимальних температур [4, 21]. Серед пріоритетних функцій флавоноїдів у листках багатьох видів рослин $є$ захист від яскравого світла й ультрафіолетового випромінювання - потенційно небезпечного внаслідок пошкодження ДНК, білків мембран $[11,12]$.

Антоціани містяться у клітинному соці вакуолей епідермальних клітин генеративних (квітки, пилок, плоди, насіння) і вегетативних (стебла, листки, корені) органів [2, 17, 19]. Згідно з даними Г. Бріттонома [1], невелика кількість флавоноїдів міститься у хлоропластах рослин, хоча загальноприйнятою $\epsilon$ думка про те, що антоціани не беруть участі у фотосинтетичних процесах. Однак, було розроблено концепцію про біологічну роль червоних пігментів у фотосинтезі рослин, відповідно до якої антоціани червонолистих рослин змінюють оптику листка [14], підвищують поглинання сонячної енергії в межах видимого спектра (380-700 нм) в середньому на

\section{Інформація про авторів:}

Левон Володимир Федорович, канд. хім. наук, ст. наук. співробітник, відділ акліматизації плодових рослин. Email: vflevon@gmail.com; https://orcid.org/0000-0003-2652-9984

Скрипченко Надія Василівна, канд. біол. наук, ст. наук. співробітник, відділ акліматизації плодових рослин. Email: actinadiia@gmail.com; https://orcid.org/0000-0002-1233-9920

Горбенко Наталія Євгенівна, канд. с.-г. наук, доцент, кафедра ботаніки, деревинознавства та недеревних ресурсів лісу. Email: nata.horbenko@gmail.com; https://orcid.org/0000-0002-6053-6582

Цитування за ДСтУ: Левон В. Ф., Скрипченко Н. В., Горбенко Н. Є. Сезонна динаміка вмісту антоціанів у деревних плодових ліанах. Науковий вісник НЛтУ України. 2020, т. 30, №5. С. 15-19.

Citation APA: Levon, V. F., Skrypchenko, N. V., \& Horbenko, N. Ye. (2020). The seasonal dynamics of the anthocyanins content in the woody fruit vines. Scientific Bulletin of UNFU, 30(5), 15-19. https://doi.org/10.36930/40300502 
$8-12 \%[6,23]$.

Встановлено, що кількість антоціанів збільшується на певній стадії розвитку рослин чи під дією стресу, оскільки тимчасовий характер їх накопичення дає рослинам змогу швидко реагувати на зміну навколишнього середовища $[2,15]$. Л. Чалкер-Скот [2] дослідив, що антоціани виконують роль осмопротекторів у листках за умов водного стресу. Навесні та восени за дії низьких температур ці пігменти з'являються у листках та стеблах рослин і слугують вибірковими фізико-хімічними "фільтрами-пастками" для сонячних променів [22], перетворюють світлову енергію на теплову і захищають рослини від холоду [3]. Це свідчить про те, що антоціани необхідні рослинам не тільки для приваблювання комах-запилювачів та розповсюдження насіння, але й для захисту від різних видів стресу.

Оскільки стимулювання синтезу антоціанів пов'язано із впливом різних стресових факторів навколишнього середовища, їх вміст певною мірою можна вважати біохімічним маркером стресового стану рослин за переохолодження, забруднення важкими металами, посухи тощо. Тому можна припустити, що динаміка вмісту антоціанів у різних органах рослин за умов інтродукції слугуватиме показником їх адаптації.

Schisandra chinensis та окремі види роду Actinidia Lindl. - ие перспективні плодові та лікарські культури для Лісостепової зони України. Плоди їх вирізняються високим вмістом біологічно активних речовин (БАР), вживаються у свіжому вигляді, використовуються в харчовій та переробній промисловості, медицині та парфумерії та ін. [5, 16]. У природних умовах плодові ліани поширені в помірних та субтропічних районах північної півкулі. За умов інтродукції рослини проходять повний цикл свого розвитку: наприкінці березня вступають у період вегетації з появою листків на початку квітня, а завершують його у жовтні і переходять до стану спокою. Досліджувані ліани - це мезофіти, для яких властива обмежена здатність переносити грунтову та повітряну посуху, яка останнім часом часто відзначається в лісостеповій зоні України. Для оцінювання стійкості цих малопоширених рослин до комплексу екологічних факторів за умов інтродукції було досліджено динаміку вмісту антоціанів в їх корі та листках.

Об'єкт дослідження - деревоподібні плодові ліани роду Actinidia Lindl. та виду Schisandra chinensis (Turcz.) Baill.

Предмет дослідження - методи і засоби визначення вмісту антоціанів у рослин деревних плодових ліанах для з'ясування інформативності цього показника під час оцінювання адаптивного потенціалу рослин в умовах інтродукції.

Мета роботи - оцінювання стійкості малопоширених плодових ліан родів Actinidia Lindl. та Schisandra chinensis (Turcz.) Baill. до комплексу екологічних факторів за умов інтродукції.

Для досягнення зазначеної мети визначено такі основні завдання дослідження: визначити вміст антоціанів у рослин деревних плодових ліанах, щоб з'ясувати інформативність цього показника для оцінювання адаптивного потенціалу рослин в умовах інтродукції.

Наукова новизна отриманих результатів дослідження - вперше розроблено методику, яка дає змогу отримати дані щодо вмісту антоціанів у різних органах деревних плодових ліан у період спокою та вегетації.
Отримані результати мають практичне значення для розроблення ефективних технологій вирощування деревоподібних ліан, які є цінними плодовими та лікарськими культурами.

Практична значущість результатів дослідження можуть бути використані для опрацювання методу оцінювання адаптивності деревних плодових ліан за умов інтродукції та для використання в селекції актинідії.

Матеріали та методи дослідження. Вміст антоціанів досліджували у пагонах, листках та плодах витких дводомних ліан, зокрема видів і сортів роду Actinidia Lindl. та виду $S$. chinensis, що зростають на експериментальних ділянках Національного ботанічного саду ім. М. М. Гришка. Об'єктом дослідження слугували: A. kolomikta (Rupr. \& Maxim.) Maxim., A.polygama (Siebold \& Zucc.) Maxim., A. macrosperma C. F. Liang, (Actinidia arguta var. purpurea (Rehder) C. F. Liang ex Q. Q. Chang, надалі A. purpurea), A. arguta (Siebold \& Zucc.) Planch. ex Miq., сорти з зеленими плодами: 'Київська крупноплідна', 'Сєнтябрьская'; сорти з пурпуровими плодами: 'Пурпурова садова', 'Надія', 'Рубінова'; сорти з зеленопурпуровим забарвленням плодів: 'Загадкова', 'Ласунка'; сорт-запилювач 'Дон Жуан'. Зразки відбирали в період спокою рослин на початку вегетації, до та після спекотного періоду в період вегетації, на початку достигання плодів та в стадії їх повної зрілості впродовж 2016-2018 рр. Кількісне визначення вмісту антоціанів проводили у висушеній корі, листках та плодах середнього ярусу крони, висушених за кімнатної температури і подрібнених в електричному млині.

Кількість антоціанів визначали спектрофотометричним методом за довжини хвилі 530 нм, використовуючи спиртову витяжку з гомогенату рослинної сировини, підкислену 3,5 \%-ною соляною кислотою [10]. Оптичну густину вимірювали на спектрофотометрі Zalimp KF 77 (Польща). Отримані дані щодо вмісту антоціанів розраховували за такою формулою:

$$
C=\frac{D \cdot V \cdot R \cdot H \cdot K}{l \cdot m},
$$

де: $D$ - оптична густина розчину; $V$ - загальна кількість екстракту (мл); $R$ - кратність розведення розчину; $l$ робоча довжина кювети (см); $H$ - аліквотна частина; $m$ - наважка (г); $K$ - коефіцієнт перерахунку.

Дослідження виконано у триразовій повторності. Точність методу становила 2,5-4,8 \%. Статистично оброблені дані відображено на гістограмах у вигляді середніх арифметичних значень та їх стандартних похибок. Статистичний аналіз виконували за допомогою програми IBM SPSS Statistics, реліз 23.0. Рівень достовірності встановили на рівні $95 \%$.

\section{Результати дослідження та їх обговорення}

Проаналізувавши вміст антоціанів у корі плодових деревних ліан упродовж року, встановлено видову специфіку їх накопичення (рис. 1). Кількість антоціанів у вегетативних органах рослин змінюється в онтогенезі та залежить від різних чинників навколишнього середовища. Відзначено два піки з максимальним вмістом антоціанів у пагонах ліан, що припадають на період спокою рослин з мінімальною температурою $\left(-18^{\circ} \mathrm{C}\right)$ та на посушливий період 3 високою температурою $\left(+32^{\circ} \mathrm{C}\right)$ повітря.

У період спокою всі досліджувані рослини реагували на істотне зниження температури підвищенням вміс- 
ту антоціанів у корі пагонів, що узгоджується з дослідженнями Н. Г. Красової [9], яка показала, що антоціани захищають рослини від дії низьких температур. Найбільшу кількість антоціанів відзначено в середині січня, хоча найнижчі температури фіксували у першій декаді місяця. Це може бути зумовлено переходом рослин зі стану глибокого до вимушеного спокою, коли навіть незначні зниження температури спричиняли істотне підвищення вмісту антоціанів у пагонах рослин. Водночас, у стані органічного спокою рослини були менш чутливі до значних знижень температури.

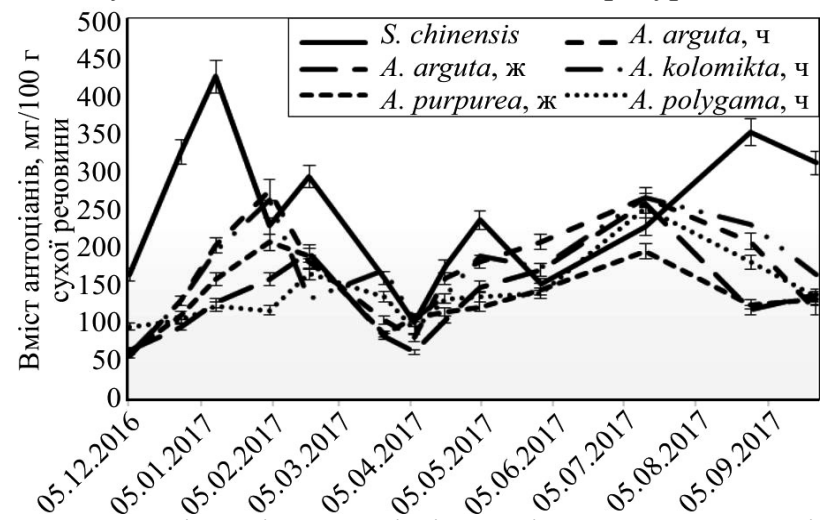

Рис. 1. Динаміка вмісту антоціанів у корі $S$. chinensis та чоловічих і функціонально жіночих форм A. arguta, A. kolomikta, A. purpurea та A. polygama впродовж року

Найнижчий вміст антоціанів виявлено на початку вегетації рослин (квітень), коли їх кількість у пагонах дослідних рослин становила 45-100 мг/100 г с. р. Порівняння вмісту антоціанів у рослинах різних видів та різної статі в період вимушеного спокою (лютий 2017 р.) показали, що пагони менш зимостійких рослин актинідії вирізнялись вищим вмістом антоціанів. Зокрема, всі чоловічі рослини $A$. kolomikta, A. arguta та $A$. purpurea, які за нашими дослідженнями менш зимостійкі порівняно 3 функціонально жіночими [20], накопичували 263-276 мг/100 г сухої речовини (с. р.) антоціанів, тоді як жіночі - 159-208 мг/100 г с. р. відповідно (рис. 2). Для A. polygama спостерігалась протилежна залежність, зокрема у корі чоловічих рослин вміст антоціанів був нижчий порівняно $з$ функціонально жіночими, що свідчить про видоспецифічність накопичення цих речовин рослинами актинідії. Найнижчий вміст антоціанів характерний для $S$. chinensis $(230$ мг/100 г с. р.), який вирізняється вищою зимостійкістю порівняно 3 дослідними видами актинідії.

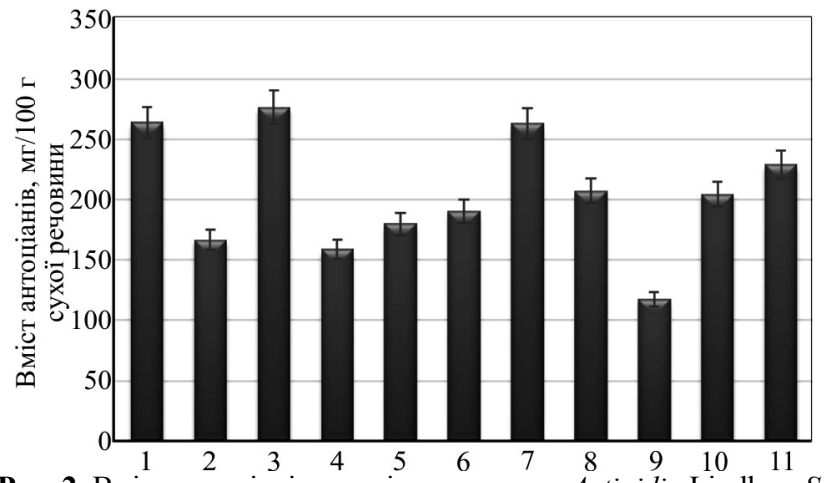

Рис. 2. Вміст антоціанів у корі рослин роду Actinidia Lindl. та $S$. chinensis на початку вегетації (квітень 2017 р.): 1 - A. kolo-

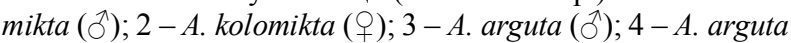
(); 5 - сорт 'Київська крупноплідна'; 6 - сорт 'Дон Жуан'; 7 - A. purpurea (ठ); 8 - A. purpurea $(+) ; 9-$ A. polygama $\left({ }_{(}\right)$; $10-$ A. macrosperma ()); $11-S$. chinensis
Водночас, вміст антоціанів у листках був у 2,23,8 раза вищим, ніж у пагонах. Найвищим вмістом антоціанів у цей період вирізнялись як листки, так і пагони S. chinensis (рис. 3).

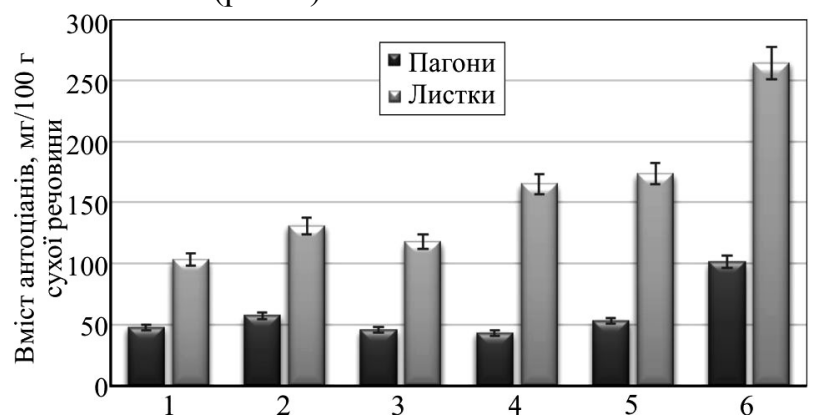

Рис. 3. Вміст антоціанів у пагонах і листках ліан на початку вегетації (квітень 2016 р.): 1 - A. kolomikta; 2 - A. macrosperma; $3-A$. polygama; $4-A$. purpurea $; 5-A$. arguta $; 6-S$. chinensis

Надалі кількість антоціанів у вегетативних органах дослідних рослин поступово збільшується, хоча стрес, спричинений високими температурами та різко вираженим дефіцитом вологи зі збільшенням втрат води через випаровування, зумовлює істотне підвищення вмісту антоціанів, після чого відбувається його зниження. Виявлено, що коли температура повітря сягала $+32^{\circ} \mathrm{C}(3-$ 5 серпня 2017 р.), збільшувалась кількість антоціанових пігментів у листках усіх дослідних об'єктів, що дає підставу розглядати підвищення їх вмісту як неспецифічну реакцію рослин у відповідь на несприятливі умови середовища.

По завершенню спекотного періоду кількість антоціанів у листках рослин зменшилась на 21-66 \% (рис. 4), що збігається з пригніченням фотосинтетичних процесів умовами посухи. Подібну реакцію рослин на дію посухи та високої температури виявлено в дослідженнях $[7,15]$.

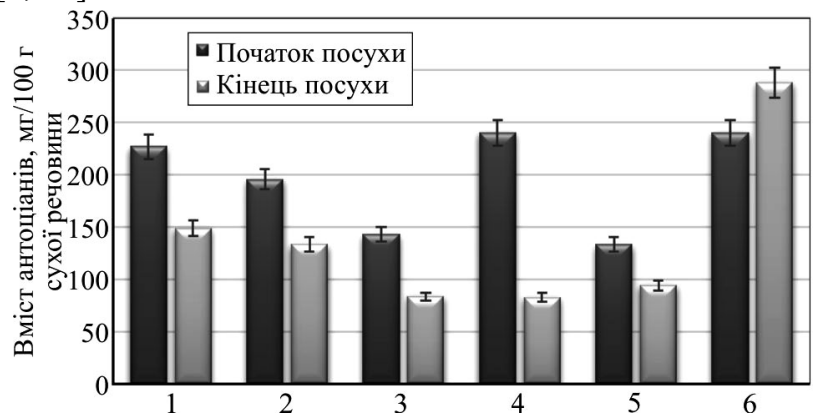

Рис. 4. Вміст антоціанів у листках видів роду Actinidia Lindl.

та S. chinensis у період літньої посухи (серпень 2017 р.): 1 -

A. kolomikta; $2-A$. arguta; $3-$ A. purpurea $4-A$. polygama; 5

- A. macrosperma; 6 -S. chinensis

У листкаx $S$. chinensis відзначено протилежну тенденцію - по завершенню періоду посухи вміст антоціанів зріс на $20 \%$. На нашу думку, це може бути пов'язано 3 тим, що $y S$. chinensis стадія тривоги триваліша за часом згідно з теорією стресу Г. Сельє [18]. Це свідчить про вищий рівень стійкості ліан роду Actinidia Lindl. до високотемпературного стресу, ніж у $S$. chinensis.

3 червня у листках деревних ліан спостерігається поступове посилення синтезу антоціанів, яке триває до серпня з подальшим зменшенням їх кількості. У вересні (відбір зразків 25.09.2017 р.) вміст антоціанів у листках деревних ліан виявився дещо нижчим порівняно 3 літнім періодом. Максимальний вміст антоціанів виявили 
у листках і черешках $S$. chinensis (до 312 мг/100 г с. p) та листках A. kolomikta (125-160 мг/100 г с. р.). Це може бути пов'язано з особливостями їх розвитку, оскільки рослини цих видів на той час вже відплодоносили і завершують вегетацію. Варто зазначити, що в цей період у листкових пластинках кількість антоціанів була вища порівняно з черешками (на 25-78 \%) (рис. 5). Найбільшу різницю за вмістом антоціанів в листках та черешках відзначено для рослин A. kolomikta, які вирізняються найкоротшим періодом вегетації порівняно з іншими видами актинідії. Найменший вміст антоціанів властивий для сортів A. arguta, які перебувають у фазі достигання плодів.

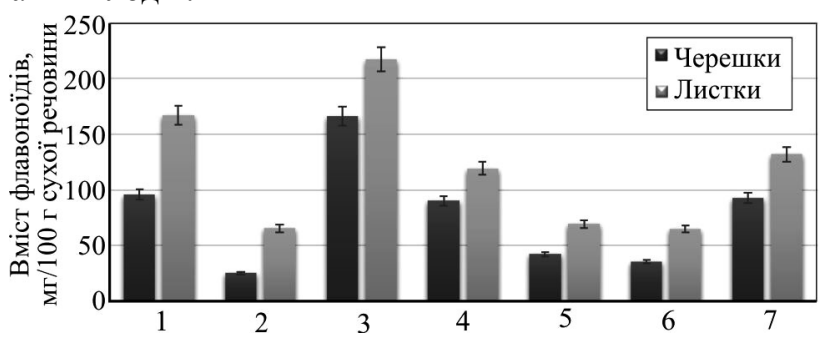

Pис. 5. Вміст антоціанів у листках ліан роду Actinidia Lindl. та

S. chinensis перед листопадом (вересень 2017 р.): 1 - A. kolomikta (†); 2 - A. arguta (†); 3 - S. chinensis; 4 -A. purpurea

(官) 5 - сорт 'Дон Жуан'; 6 - сорт 'Київська крупноплідна'; 7 - A. macrosperma

На початку достигання плодів вміст антоціанів у листках актинідії був значно вищий (у 5-11 разів) порівняно з їх кількістю у плодах (рис. 6). До того ж листки червоноплодих сортів вирізнялись вищим вмістом антоціанів порівняно з зеленоплодими. Тому можна припустити, що вміст антоціанів у листках актинідії на ранніх етапах розвитку рослин може слугувати індикатором кольору їх плодів при вступі в генеративний період розвитку, що дуже важливо для селекційної роботи, одним 3 напрямків якої є відбір червоноплодих форм. Тому це питання досить актуальне і потребує подальших досліджень.

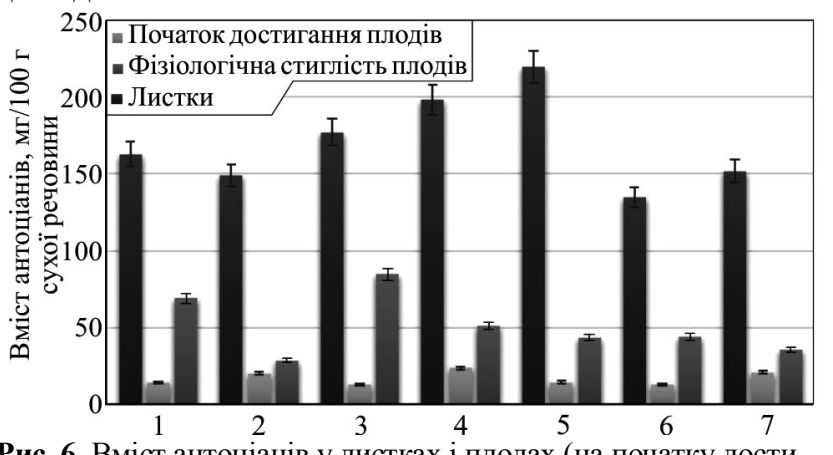

Рис. 6. Вміст антоціанів у листках і плодах (на початку достигання та на стадії фізіологічної стиглості плодів) деяких сортів актинідії (вересень 2017 р.): 1 - 'Помаранчева'; 2 'Загадкова'; 3 - 'Рубінова'; 4 - 'Пурпурова садова'; 5 - 'Надія'; 6 - 'Ласунка'; 7 - 'Сєнтябрьская'

У період фізіологічної стиглості вміст антоціанів у плодах збільшився в 1,4-4,7 раза порівняно з початком ïх достигання і сягав 30-85 мг/100 г с. р., з максимумом у плодах з червоним забарвленням. Результати наших досліджень узгоджуються 3 даними робіт $[18,21]$, які також виявили більшу кількість антоціанів у плодах із пурпуровим забарвленням у плодах $A$. arguta, $A$. purpu$r e a, A$. arguta х $A$. melanandra, що ідентифікувались головним чином як пеларгонідин і частково ціанідин i дельфінідин.
Варто зазначити, що в цей час червоні плоди актинідії сортів 'Надія' та 'Пурпурова садова' характеризувались нижчим вмістом антоціанів порівняно із плодами сорту 'Загадкова', плоди якого зелено-червоні з червоною серцевиною. Високим вмістом антоціанів вирізнялись плоди жовтоплодого сорту актинідії 'Помаранчева' (A. polygama), а найменшим - зелені плоди актинідії 'Сєнтябрьская'. Також варто зазначити, що корелятивний зв'язок між вмістом антоціанів у листках та плодах слабкий і становить 0,29 (таблиця).

Таблиця. Вміст антоціанів у листках та плодах деяких сортів актинідії та кореляційний зв'язок між ними

\begin{tabular}{|c|c|c|c|}
\hline \multirow{2}{*}{ Сорт } & \multirow{2}{*}{$\begin{array}{c}\text { Забарвлення } \\
\text { плодів }\end{array}$} & \multicolumn{2}{|c|}{ Вміст антоціанів } \\
\hline & & у листках & у плодах \\
\hline $\begin{array}{l}\text { 'Пурпурова } \\
\text { садова' }\end{array}$ & пурпурове & $198,1^{ \pm 4,75}$ & $51,43^{ \pm 1,21}$ \\
\hline 'Сєнтябрьская' & зелене & $151,86^{ \pm 3,64}$ & $35,56^{ \pm 0,84}$ \\
\hline 'Надія' & пурпурове & $219,47^{ \pm 5,27}$ & $43,85^{ \pm 1,03}$ \\
\hline 'Загадкова' & зелено-пурпурове & $148,78^{ \pm 3,57}$ & $28,86^{ \pm 0,68}$ \\
\hline 'Ласунка' & зелено-пурпурове & $134,86^{ \pm 3,24}$ & $44,35^{ \pm 1,04}$ \\
\hline 'Рубінова' & пурпурове & $177,05^{ \pm 4,25}$ & $84,71^{ \pm 1,99}$ \\
\hline \multicolumn{2}{|c|}{ Коефіцієнт кореляції } & \multicolumn{2}{|c|}{0,29} \\
\hline
\end{tabular}

\section{Висновки}

На основі отриманих даних встановлено, що реакцією рослин на дію низьких зимових температур та високих температур із вираженим дефіцитом вологи влітку є підвищення вмісту антоціанів, що зумовлено їх участю в механізмах адаптації рослин до несприятливих факторів середовища.

Ендогенний рівень антоціанових пігментів у вегетативних органах рослин можна використовувати для прогнозу успішності інтродукції рослин у нові умови та відбору сортів із високою адаптивною здатністю.

Вміст антоціанів у листках рослин актинідії можна розглядати як індикатор червоноплодості у селекції рослин на ранніх стадіях їх розвитку, але це питання потребує докладнішого вивчення.

\section{References}

1. Britton, G. (1986). Biohimiya prirodnyh pigmentov. Moscow: Mir, 422 p. [In Russian].

2. Chalker-Scott, L. (2002). Do anthocyanins function as osmoregulators in leaf tissues? Advances in Botanical Research, 37, 103127. https://doi.org/10.1016/s0065-2296(02)37046-0

3. Chub, V. I. (2008). What are anthocyanins for?. Floriculture, 6 , 22-25. [In Russian].

4. Chupakhina, G. N., Maslennikov, P. V., \& Skrypnik, L. N. (2011). Natural antioxidants (environmental aspect). Kaliningrad: I. Kant Baltic Federal University Publishing House, 111 p. [In Russian].

5. Djurenko, N. I., Skrypchenko, N. V., \& Slusar, G. V. (2017). Biochemical features of the fruits of Schizandra chinensis (Turcz.) Baill.). Medical and clinical chemistry, 2(201), 38-44. https://doi.org/10.11603/mcch.2410-681X.2017.v0.i2.7969

6. Jaakola, L. (2004). Activation of flavonoid biosynthesis by solar radiation in bilberry (Vaccinium myrtillus L.) leaves. Planta, 218(5), 721-728. https://doi.org/10.1007/s00425-003-1161-x

7. Kalita, T. M. (2013). Seasonal dynamics of flavonoid accumulation in different species of the genus Rhododendron L. as a marker of acclimatization reactions. Industrial botany, 13, 158-162. [In Ukrainian].

8. Kosulina, L. G., Lutsenko, E. K., \& Aksenova, V. A. (1993). Physiology of plant resistance to adverse environmental factors. Rostov-na-Donu: Rostov University Publishing House, 240 p. [In Russian]. 
9. Krasova, N. G., Galasheva, A. M., Ozherelieva, Z. E., Golyshkina, L. V., \& Makarkina, M. A. (2014). About apple tree resistance to unfavorable winter conditions. Agricultural biology, 1, 42-49. [In Russian].

10. Kriventsov, V. I. (1982). Methodical recommendations for the analysis of fruits for biochemical composition. Yalta: State Nikitsky Botanical Gardens publishing house, 21 p. [In Russian].

11. Latocha, P. (2010). Morphology and utility value of Actinidia arguta (Siebold \& Zucc.) Planch. ex Miq., A.arguta x a.purpurea Rehd. fruits. Warsawa: Wies Jutra, 108 p. [In Polish].

12. Lovelock, C. E., Clough, B. F., \& Woodrow, I. E. (1992). Distribution and Accumulation of Ultraviolet-radiation absorbing Compounds in Leaves of Tropical Mangroves. Planta, 188(2), 143154. https://doi.org/10.1007/BF00216808

13. Makarenko, O. A., \& Levitsky, A. P. (2013). Physiological functions of flavonoids in plants. Physiology and biochemistry of cultivated plants, 45(2), 100-112. [In Russian].

14. Merzliak, M. N. (1998). Pigments, leaf optics and plant health. Soros educational journal, 4, 19-24. [In Russian].

15. Nenko, N. I., Kiseleva, G. K., Ulyanovskaya, E. V., Yablonskaya, E. K., \& Karavayeva, A. V. (2019). Physiological and biochemical criteria of apple tree resistance to abiotic stresses of the summer period. Agricultural biology, 54(1), 158-168. https://doi.org/10.15389/agrobiology.2019.1.158rus

16. Nowak, A., Zakłos-Szyda, M., Błasiak, J., Nowak, A., Zhang, Z., \& Zhang, B. (2019). Potential of Schisandra chinensis (Turcz.)
Baill. In Human Health and Nutrition: A Review of Current Knowledge and Therapeutic Perspectives. Nutrients, 11(2), 333. https://doi.org/10.3390/nu11020333

17. Seager, N. (1997). Sinthesis and degradation of Anthocyanins in Actinidia arguta x A. melanandra. Acta Hort., 444, 523-528. https://doi.org/10.17660/ActaHortic.1997.444.80

18. Selye, H. (1982). Stress without distress. Moscow: Progress, 127 p. [In Russian].

19. Semkina, L. A., \& Shavnin, S. A. (2016). On the physiological role of permanent and temporary accumulation of anthocyanin pigments in the leaves of woody plants. Journal of General Biology, 77(6), 434 441. [In Russian].

20. Skrypchenko, N. V., Nuzhina, N. V., Dzyuba, O. I., \& Slyusar, G. V. (2018). Anatomic structure of one-years-old shoots of actinidia species. Plant introduction, 2(78), 29-36.

21. Tanchev, S. S. (1980). Anthocyanins in fruits and vegetables. Moscow: Pishchevaya promyshlennost, 304 p. [In Russian].

22. Trojak, M., \& Skowron, E. (2017). Role of anthocyanins in highlight stress response. World Scientific News, 81(2), 150-168.

23. Zayats, V. A., Kivezhdzi, M. M., Makhlynetz, S. S., \& Zayats, L. M. (2006). The creating of the cultivars with dark red leaves as a means of increasing the productivity of agricultural plants. Scientific Bulletin of the Mukachevo Technological Institute, 2, 47-52. [In Ukrainian].

V. F. Levon ${ }^{1}$, N. V. Skrypchenko' ${ }^{1}$, N. Ye. Horbenko ${ }^{2}$

${ }^{1}$ M. M. Gryshko National botanical garden of the NAS of Ukraine, Kyiv, Ukraine

${ }^{2}$ Ukrainian National Forestry University, Lviv, Ukraine

\section{THE SEASONAL DYNAMICS OF THE ANTHOCYANINS CONTENT} IN THE WOODY FRUIT VINES

Introducers of Far East flora - woody vines of the Actinidia Lindl and Schisandra chinensis (Turcz.) Baill. genus are valuable fruit and medicinal plants. In order to assess plants adaptive potential under the conditions of their introduction into the forest-steppe zone and the prospects of their widespread introduction into horticulture, the content of anthocyanins in shoots, leaves and fruits of plants was determined. The amount of anthocyanins was determined by a spectrometric method. The amount of anthocyanins in the vegetative organs of plants is determined to vary in ontogenesis as well as to depend on various environmental factors. There were two peaks with the maximum content of anthocyanins in the shoots of vines, which occur during the dormancy period of plants with a minimum temperature and during the dry period with a high air temperature. All studied plants responded to a significant decrease in temperature by increasing the content of anthocyanins in the bark of shoots during the dormant period. It was found that all male plants A. kolomikta, A. arguta and A. purpurea, which according to our studies are less winter-hardy than functionally female, accumulated $263-276 \mathrm{mg} / 100 \mathrm{~g}$ dry matter (d.m.) of anthocyanins, at that time as females $-159-208 \mathrm{mg} / 100 \mathrm{~g}$ d.m. The lowest content of anthocyanins was found for $S$. chinensis, which has high winter hardiness compared to experimental species of actinidia. There was an increase in the amount of anthocyanin pigments in the leaves of all research objects during the summer drought, which makes it possible to consider their increased synthesis as a non-specific reaction of plants in response to adverse environmental conditions. At the end of the hot period, the amount of anthocyanins in the leaves of plants decreased by $21-66 \%$, which coincides with the suppression of photosynthetic processes by drought conditions. The content of anthocyanins in the leaves of actinidia was much higher compared to their number in the fruit at the beginning of fruit ripening. In addition, the leaves of red-fruited varieties had a higher content of anthocyanins compared to green-fruited. Therefore, we can assume that the content of anthocyanins in the leaves of actinidia in the early stages of plant development can serve as an indicator of the color of their fruits when entering the generative period of development, which is important for breeding work, one of which is the selection of red fruits.

Keywords: Actinidia Lindl.; Schisandra chinensis (Turcz.) Baill.; introduction; plant pigments; frost hardiness. 